\title{
A New Treatment Option for Amyotrophic Lateral Sclerosis: Edaravone
}

\author{
Amiyotrofik Lateral Skleroz Tedavisinde Yeni Bir Seçenek: Edaravone
}

Keywords: Amyotrophic lateral sclerosis, treatment, edaravone, neuromuscular disorders

Anahtar Kelimeler: Amiyotrofik lateral skleroz, tedavi, edaravone, nöromusküler hastalıklar

\section{A New Treatment Option for Amyotrophic Lateral Sclerosis: Edaravone}

Amyotrophic lateral sclerosis (ALS) is a neurodegenerative disorder characterized by upper motor neuron, corticospinal tract, and lower motor neuron involvement. In 1874, Jean-Martin Charcot described the disease as follows: "The common findings we observed in a group of patients were spasm and paralysis in the upper extremities and mainly in the lower extremities without sensory loss along with progressive amyotrophy involving especially the upper extremities and body and this explanation still remains current. The most detailed studies on the epidemiology of the disease have been carried out in Europe and its prevalence is 2.6-3/100,000. It is more common in males aged 50-75 years. ALS is one of the most difficult diseases for neurologists to manage because of its high morbidity and mortality, and has been a focus of attention in recent years with advances in treatment.

Riluzole was the first drug to be approved for ALS treatment and it acts as a glutamatergic transition modulator. Demonstration of motor neuron damage due to glutamate excitotoxicity in ALS pathophysiology has opened the way for drug trials; riluzole has been shown to increase survival in patients with ALS by 3 months (1). Oxidative stress, mitochondrial dysfunction, abnormal protein aggregation, and autoimmunity are thought to be other underlying mechanisms, and these mechanisms form the basis of clinical research along with stem cell studies.
Edaravone is a potent antioxidant and has been used in Japan for the treatment of ischemic stroke since 2001 and for the treatment of ALS since 2015. It has been shown that the reduction of ALS functional rating scale for motor and bulbar functions is $33 \%$ less in patients with ALS treated with the edaravone, which affects the oxidative stress mechanism compared with placebo (2). However, even though the data obtained demonstrate that the benefit is limited and does not prolong survival, the drug has been approved by the United States Food and Drug Administration and is being used in the treatment of ALS.

Although phase 2 trials with talampanel, an anti-glutamate agent, and dexpramipexole, both an antioxidant and a mitochondrial protector, showed beneficial effects, subsequent studies have revealed that they have no benefit (3). Stem cell therapy is different from other therapies because it aims to increase the amount of cells instead of reducing motor neuron damage, and significant results have been achieved in phase 1 studies. However, because the research in this area is very recent, a consensus has not yet been reached on which stem cells to use and the place/method of implantation in treatment. Clinical trials up to now have not yet shown a benefit, but the results of ongoing trials are eagerly awaited.

As a result, edaravone has been used as an option in the management of the disease after 22 years of treatment approval. The beginning of the understanding of mechanisms that cause the disease at the molecular level has provided new targets for

\footnotetext{
Address for Correspondence/Yazışma Adresi: Erdi Şahin MD, Istanbul University Istanbul Faculty of Medicine, Department of Neurology, Istanbul, Turkey Phone: +90 5374190831 E-mail: erdisahin@gmail.com ORCID ID: orcid.org/0000-0002-5792-2888

Received/Geliş Tarihi: 02.07.2017 Accepted/Kabul Tarihi: 24.07.2017

${ }^{\circ}$ Copyright 2018 by Turkish Neurological Society

Turkish Journal of Neurology published by Galenos Publishing House.
} 
treatment in recent years. Stem cell studies are expected to be at the forefront of these targets in the coming years. Although ALS continues to be a disease with poor prognosis, developments give us hope for potential treatments.

\section{References}

1. Miller RG, Mitchell JD, Lyon M, Moore DH. Riluzole for amyotrophic lateral sclerosis (ALS)/motor neuron disease (MND). Cochrane Database Syst
Rev 2007:CD001447.

2. Writing Group; Edaravone (MCI-186) ALS 19 Study Group. Safety and efficacy of edaravone in well defined patients with amyotrophic lateral sclerosis: a randomised, double-blind, placebo-controlled trial. Lancet Neurol 2017; 16:505-512.

3. Pascuzzi RM, Shefner J, Chappell AS, Bjerke JS, Tamura R, Chaudhry V, Clawson L, Haas L, Rothstein JD. A phase II trial of talampanel in subjects with amyotrophic lateral sclerosis. Amyotroph Lateral Scler 2010;11:266271. 